\title{
Zambia: \\ Assertion and Resistance. Reading Conflicts between the Zimbabweans and the Indian Diaspora
}

\author{
Sasmita MOHANTY
}

\begin{abstract}
Over the period, the relationship between the native communities and the diaspora has become one of the incompatible relationship, and thereby led to the emergence of mistrust, division and resentment among the native communities. This has become more conspicuous concerning the native communities and the Indian diaspora in Zimbabwe (former Rhodesia). Within this backdrop, bringing the debate on the insider versus outsider, the article presents a complex picture of contemporary community conflicts between the native communities and Indian diaspora in Zimbabwe. The paper discusses the context and reasons of ethnic assertion among the native communities and their resistance towards the Indian diaspora. It explores the role of the state in the entire episodes of community conflicts in Zimbabwe. It argues that though the Indians are politically minority community, they have established their dominant position in economic sphere, and the economic prosperity of the Indian diaspora community has much contributed to the emergence of community conflicts in Zimbabwe.
\end{abstract}

Keywords: ethnic assertion, resistance, community conflict, Indian diaspora, Zimbabwe.

\section{Introduction}

Diaspora study has become one of the critical arenas of political discourse in the contemporary academic arena across the globe. Such discourse has emerged not only because of the nature of contributions that the diaspora community makes towards the host country but prominently due to the nature of relationship that has been established between the diaspora and native communities. Over the period, the relationship between the native communities and

\author{
Sasmita MOHANTY \\ Department of Political Science \\ Rajdhani College, University of Delhi \\ E-mail: sas1jnu@gmail.com \\ Conflict Studies Quarterly \\ Issue 33, October 2020, pp. 42-52
}

DOI: $10.24193 / \mathrm{csq} .33 .3$

Published First Online: 05 October /2020 
the diaspora has become one of the incompatible relationships, and thereby led to the emergence of mistrust, division and resentment among the native communities. This has become more conspicuous concerning the native communities and the Indian diaspora in Zimbabwe (former Rhodesia). Different levels of social, economic and political developments experienced by them has led to the emergence of incompatible and contested relationships, and thereby creating a situation of conflict, violence and dissonance. This simply highlights assertion, aggression, antagonism and resistance of the native Zimbabwean communities towards the Indian diaspora community. Within this backdrop, Zimbabwe is experiencing a series of conflicts, both ethnic and resource conflicts, between the Zimbabweans and Indian diaspora. Their distinct ethnic identities have become the ground for generating conflicts and gradually the ethnic conflicts have taken the form of resource conflicts in Zimbabwe.

Within this backdrop, bringing the debate on the insider versus outsider, the article presents a complex picture of contemporary community conflicts between the native communities and Indian diaspora in Zimbabwe. The paper discusses the context and reasons of ethnic assertion among the native communities and their resistance towards the Indian diaspora. It explores the role of the state in the entire episodes of community conflicts in Zimbabwe. It argues that though the Indians are politically minority community, they have established their dominant position in economic sphere, and the economic prosperity of the Indian diaspora community has much contributed to the emergence of community conflicts in Zimbabwe.

\section{Diaspora, Ethnic Identities and Conflict}

The relationship between diaspora and conflict has been well crafted by numerous scholars (Collier, 2000; Shain, 2002; Brinkerhoff, 2011; Van Hear \& Cohen, 2016; Mariani, Mercier, \& Verdier, 2018). They increasingly focus on the role of diaspora in conflict as well as post-conflict situation in countries of origin. Collier $(2000$, p. 14) considers that the diaspora usually involved in generating conflict because of their sound economic position and they do not necessarily go through the ordeals of conflict in the country of their origin. To quote Collier (2000), "They are much richer than the people in their country of origin and so can afford to finance vengeance. Above all, they do not have to suffer any of the awful consequences of renewed conflict because they are not living in the country" (p. 14). Shain (2002) also discusses the role of diaspora involvement in the conflict in the country of their origin. Brinkerhoff (2011) explores the relationship between diaspora and conflict in the way of engagement of diaspora in conflict societies. Brinkerhoff (2011) discusses the contribution of diaspora and their potential positive and negative impact over the countries experiencing conflicts, especially in the context of their country of origin. Van Hear and Cohen (2016) contextualised the role of diaspora in conflict with resources, social capital and class that the diaspora communities posses. However, the engagement of diaspora community 
in conflictual relationship with the native communities has hitherto been neglected by the existing literature. Dotson and Dotson (1968) explore the community relationship between the Indian diaspora and native Zimbabwean communities, with an indication of incompatible relationship between them.

The incompatible relationship is the product of the larger debate on 'we' versus 'others', insiders versus outsiders, natives versus migrants, etc. These discourses take place along the line of native communities as insiders and the diaspora community as the outsiders or migrants. These binary debates usually provoke people to align themselves along the line of ethnicity. The process of such identification of the self also lead to the emergence of ethnic consciousness at the community level, which is different from other communities. To put it differently, identities are contextual and people develop their distinctive individual as well as community ethnic identities on the basis of their day to day interaction with the 'other'.

Brass (1985) defines ethnic community 'as an ethnic category that has adopted one or more of its marks of its cultural distinctness as used them as symbols both to create internal cohesion and to differentiate itself from other ethnic groups' (p. 17). An ethnic category, for Brass (1985) is "any group of people in terms of objective cultural criteria and that contain within its membership either in principle or in practice the elements for a complete division of labor and for production" (p. 17). Yinger (1997, pp. 3-4) considers three contexts to understand the ethnic communities/groups: (i) the group is perceived by others in society to be different in some combination of the following traits: language, religion, race and ancestral homeland with its related culture; (ii) the members also perceive themselves as different; and (iii) they participate in shared activities built around their common origin and culture.

Brass (1985) equates ethnic identity formation with a process that reflects three sets of struggles. One takes place within the ethnic group itself to control over its material and symbolic resources, which in turn involves defining the group's boundaries and its rules for inclusion and exclusion. The second takes place between ethnic groups as a competition for rights, privileges and available resources. The third takes place between the state and the group that dominate it and the population that inhibits its territory. Such ethnic identity formation can facilitate the process of ethnic assertion.

Ethnic assertion is nothing but the process of reconfiguring community distinct identities along the line of ethnicity. Ethnic assertion can crate the platform for the emergence of ethnic conflict. Ethnic conflict can sometimes be called as cultural conflicts because of the distinctive cultural differences that wide the ethnic differences (Horowitz, 1985). Ambagudia (2019) stated that various ethnic identities creates the regime of 'ethnic deprivation' while competing scarce natural resources, state sponsored privileges, opportunities and entitlements. Ethnic deprivation can also lead to the feeling of, what Ted Robert Gurr (1970) considers as, 'relative deprivation'. Relative deprivation is the 
product of the ethnic comparison in social, economic, cultural and political spheres between ethnic communities.

Horowitz (1985) and Ambagudia (2019) argue that ethnic comparison would posit the communities in advantaged and disadvantaged positions along the line of their ethnic identities, and thereby precipitating the process of ethnic assertion among the communities more prominently. Hence, Horowiz argues that ethnic comparison is one of the prominent reasons of community conflicts. Community conflicts between the native and diaspora/migrants take place due to the competition to control over and access to scarce natural resources and state sponsored opportunities and privileges by invoking their district ethnic identities.

\section{Brief History of Indians in Zimbabwe}

Zimbabwe, former Southern Rhodesia, is one of the land locked countries of Central Africa. It has a long history of immigration, which was facilitated by the then Rhodesia government, British Imperial government and private voluntary organisation (Mlambo, 1998). The Rhodesia government created social, economic and political conditions to attract the White settlers in the country. One of the Rhodesia settlers succinctly put the policy of the government, "Don't regard the country (Rhodesia) as a Black Man's country, where the white man is an intruder, an exploiter of Black labour, a superior; look on it as an empty country...to be settled with a white population..." (cited in Mlambo, 1998, p. 131).

The historical account of Indians in Zimbabwe indicates that they were brought by the British to ease their administration in Africa. Some of them also moved to the territory of Central Africa for the trade and business purposes. The Indians constituted around 30,000 out of a total regional population of perhaps 11 million (Dotson \& Dotson, 1968, p. 3). According to the Ministry of External Affairs (MEA), Government of India data, the total population of oversees Indians in Zimbabwe is 9500. Out of 9500, 500 are Non-Resident Indians and 9000 are the People of Indian Origin (Government of India Report, n.d.). The history of Indians migration to Zimbabwe indicates they have a long history of trade relation in Zimbabwe although the trade in Central Africa initiated by the Europeans. Originally, these Indians came to Africa under the umbrella of European power (Dotson \& Dotson, 1968, p. 21). Over the period, the Indians established themselves in the areas of trade and business, which has resulted in their relatively better economic condition in comparison to native Zimbabwean communities. It is worthwhile to mention that Indians constitute a politically minority community in Zimbabwe.

\section{Class Composition of Zimbabwean Society}

Zimbabwe is a plural society and a developing economy. Zimbabwe is an agrarian society and the large chunk of Zimbabwean population is involved in farming. Out of the total 
land areas of over 39 million hectares, 33.3 million hectares are used for agricultural purposes (http://www.fao.org/3/y4632e/y4632e0y.htm). As a class, they were basically self-sufficient peasant farmers. The government is, however, reluctant to promote the indigenous commercial farming (Moyo, 2000, p. 23, footnote 61), which not only affected their income generation but also largely impoverished their economic condition. Meanwhile, it has been stereotyped that the Zimbabweans, especially the Blacks, possess neither the knowledge nor the capital required for engaging in trade and commerce (Dotson \& Dotson, 1968, p. 3). However, there was an increasing demand on goods and services in Zimbabwe which were not produced locally. Hence, the vacuum occurred in the field of trade and business in Zimbabwe. In this context, the Indians emerged to fill up the vacuum created in business and trade sectors.

Gradually, there was an expansion of trade and commerce, which were carried out by the Indians. The presence of Indians in Zimbabwe is mainly drawn from the Indian state of Gujarat, who are largely involved in trade and business. The Indians played the role of middlemen in trading relationship. They have been mediating in facilitating the transfer from relatively developed areas to less developed areas which largely constitute a market. Although the Indians constitute minority in terms of their share with the total population of the country, they are very active in in trade and business sectors. The Indians have succeeded in positioning themselves in this area of occupation. However, such economic position of the Indian diaspora has not been well received by the native Zimbabwean communities, which led to the emergence of ethnic comparison in economic sphere and orchestrated the ethnic resistance against the Indian diaspora community in Zimbabwe.

\section{Understanding Conflict}

The Zimbabwean society has a long history of hosting migrants, who moved to the country for one or the other reasons, and hence, creating a category of diaspora. Such history of the country has facilitated the continuous process of interaction and interface between the native and diaspora communities in Zimbabwe, which has taken the form of ethnic interaction and interface. However, the interaction and interface between them have not been well conceived by the native communities, and thereby led to the emergence of incompatible and conflictual relationship between them. The native communities equate the Indians with exploiters, traitors and looters of economy, who are allegedly more concerned with their own economic advancement rather than contribution to the economic development of the country. Such aspects have been triggered and have contributed to their adversial economic relationship. Zimbabwean society has experienced political, social, economic and cultural domination of settler minority over the African majority (Mlambo, 1998, p. 123). As a result, assertion, resistance, contestation and conflict have become the defining features of Zimbabwean society in the contemporary period. 
The indifferent attitude towards the Indians is not the product on of the contemporary period only and the native ethnic communities of Zimbabwe are not the only actors who have developed incompatible relationship with the Indians. Such orientation was also developed at the policy level. The then Rhodesian state deliberately pursued the discriminatory administrative measures against the Indians way back in the early 1900 .

As mentioned earlier, the colonial Rhodesia government wanted to establish a White Man's country. This was not the case with all the immigrants. The immigration policy of the Rhodesia government was lenient towards certain immigrants, especially the white immigrants (the Europeans). However, the Rhodesia government developed indifferent attitudes and racially discriminatory moves against the Indian diaspora community. For instance, the Rhodesia authorities issued two ordinances, the 1903 Immigration Restriction Ordinance and Immigrants Regulation Ordinance 1914, by mandating the criteria of signing the application form in European language. It has been alleged that the Rhodesia government imposed the language criteria in the both the ordinances primarily to restrict the Indian migrants to Rhodesia because of their racial differences and to facilitate the markets to the Europeans. The Indians were seen as the capturer of the market opportunities (Mlambo, 1998, pp. 143-144). The suggestion of the Indian engineer for allocating the land unsuitable for the White settlement to the Indians went unheard and seen as generating disenchantment of Europeans towards Indian diaspora (Mlambo, 1998, p. 144). In other words, the context of the conflicting relationship with the Indian diaspora set by the state.

Such discrimination and indifferent attitudes towards the Indian diaspora community have intensified in the recent period. The Indian diasporas in Zimbabwe have been excluded from certain spaces of the state and the ownership processes because of the escalation of racial and ethnic conflict/cleansing (Muzondidya, 2004, p. 228). Meanwhile, a series of resistance and attacks were carried out against diaspora communities in different parts of the African sub-continent. One such example is the attack on Indian businessman in Uganda in the 1970s. The Ugandan leader Idi Amin expelled 60,000 Asians, mostly Indians, from Uganda in August 1972. Most of these Indians fear their lives and took asylum in Britain. Meanwhile, the government captured their homes, shops, business houses and farms (Muzondidya, 2004, p. 229; Butcher, 2002; Zee News, 2002).

The incident of Uganda invariably influenced and provoked the native communities carry out the similar attacks against Indian diaspora in Zimbabwe. The Indian diaspora community in Zimbabwe has been attacked in 2002. Similar potential attack on Indian diaspora community was also anticipated in 2017. However, the Indian embassy was quick to announce the safety and security of the Indians in Zimbabwe (PTI, 2017). During the 2002 attack, the supporters of the President Robert Mugabe are threatening the Indians to confiscate land property. The supporters of the President included the war 
veterans led by Andrew Ndlovu and the members of the black economic empowerment lobby group, the Affirmative Action Group (AAG), among others. The AAG emerged to deliver justice to the Zimbabweans. It believes that the destiny of the Zimbabweans should be decided by the Zimbabweans themselves not by the outsiders (The Herald, 2012).

The supporters considered the Indians diaspora as economic looters. They also alleged that 'nearly all the developed land in cities' are occupied by the Indian diaspora after 1980, the year new constitution came into force. Andrew Ndlovu, the Secretary of Projects for the War Veterans' Associations and supporter of the President of Zimbabwe Robert Mugabe, declared that "nothing will stop us from reclaiming commercial land from Indians. If they do not stop looting our economy, they will leave us with no choice but to go door to door making sure all Indians in the cities are complying with instructions from war veterans" (quoted in Muzondidya, 2004, p. 228). The supporters also alleged that the Indians have a major role in facilitating black market in Zimbabwe (Muzondidya, 2004, p. 228; Butcher, 2002).

The war veterans spread the seed of anti-Indian attitude in Zimbabwe. The Indian diaspora community was relegated to vulnerable position. As a result, the Indian diaspora instilled the sense of fear and insecurity in themselves in a country where their economic contributions are commendable over the period. As a part of their campaign and fulfilling their commitment to wipe out Indian from Zimbabwe, the AAG captured the property and house of the Indian businessman in a Zimbabwean city (Bulawayo). The Indians were left with no option but to vacate their houses and became homeless. They also had to lose their hard earned all land and properties. The AAG group sent out a written document to all the Indians settled in Bulawayo city and threatened to seize their property and resources.

The AAG titled the document as Indigenisation versus Indians, and thereby invoking the discourse on native versus outsiders based on their ethnic identities. The document reflected a number of provocative statements, which invariably considered Indians as exploiters, looters and oppressors, among others. The document also questioned the domination of the numerically minority Indians over the majority Zimbabweans of about two million people in Bulawayo, which has emerged as a business hub. The document alleged that less than ten Indians have captured half of the central business district (Bulawayo). The document invoked the consequences of Uganda and reflected that as long as the Indians are indulged in exploiting, marginalising and dispossessing the natives, the 'dominant position' will continue to be challenged and resisted. The document also indicated the commitment to confiscate the land and properties of Indians, so that the properties can be used for the benefits of the Black people (Muzondidya, 2004, pp. 228-229). 
With the circulation of this document, Indigenisation versus Indians, the AAG group members captured an apartment belonging to an Indian businessman, Mr Narandas Hassamal. Both the acts of AAG and the war veterans led by Andrew Ndlovu came to the notice of the government of Zimbabwe. The government was quickly responded to this act with consequences. Andrew Ndlovu was arrested and he was charged with breaching a section of the Public Order and Security Act (Muzondidya, 2004, p. 229). However, the important take away from this act is the way in which the minority Indians are being treated in this land. In spite of their long service and loyalty to the host country, they are being treated as aliens. Hence, Muzondidya (2004) underlines that the important message emerging from these developments is the way in which subject minorities have continued to be constructed as aliens in Zimbabwe's post-colonial discourse about rights and entitlements.

Now question emerges, why such incident happened in Zimbabwe? Why the Indians were targeted although there are many migrants from Europe settled in Zimbabwe, who largely migrated during the colonial period? Why these white people were not targeted although they are also economically prosperous and many are in to the business sector? On the other hand, the Europeans have been facilitated by the government for their settlement (Mlambo, 1998, p. 124). The reason is that the white settlers are strongly connected to the country of their origin and are getting strong support from the home country which was not the case with the Indians earlier. This is because after independence, India was seen involved itself in resolving the domestic issues/problems than giving attention to the Indian diaspora community abroad.

As mentioned earlier that the economic engagement of Indians has offered dividend to them, and thereby indicated their relatively sound economic position than the local communities. In this context, the economic prosperity of the Indians in Zimbabwe appeared to be the main reason for rift between the the natives and the Indian diaspora. However, there are competing propositions to understand the contested relationship between the the native communities and Indian diaspora in Zimbabwe. Muzondidya (2010) argues that the unresolved legacies of polarisation and inequality is responsible for the economic crisis in this country. This is also one of the reasons for the racial conflict in Zimbabwe which aggravated anti-Indian orientation among the natives. The political authority of Zimbabwe, instead of resolving such issues, utilised such emotive issue of racial differences to mobilise support internally, regionally and internationally (Muzundidya, 2010, p. 1).

The political authorities also directly or indirectly stand by the attackers and aggravated the situation by delaying in taking actions against the perpetrators. In this entire process, the colonial mindset of subordination is still visible among the native communities in Zimbabwe. Unfortunately, the orientalist approach towards the communities defined interns of exploiter and the exploited is somehow seen in the context of the relation- 
ship between the native and Indian diaspora communities. Hence, the Indian diaspora community tends to be trapped in this binary relationship of we versus others, insiders versus outsiders and native versus migrants, among others.

The binary understanding of communities has also led to the development of native perspective. The native ethnic communities have developed their own perception in a sense that in a situation of competition over scarce resources and geographical spaces, where the gain for Indian diaspora community has been seen as the loss for the native communities of Zimbabwe. Hence, the dichotomy of loss versus gain has led to the assertion of native communities along the line of their ethnic identities, which has created the ground for resisting the relatively advanced Indian diaspora community in the race of ethnic competition to control over and access to resources. The whole episodes of the natives' attack on Indian diaspora indicate that their distinct identities were developed corresponding to their ethnic differences between the Zimbabweans, especially the Blacks, and the Indian diaspora. Such ethnic differences gradually led to the ethnic assertion along the resource relationship and invariably resulted in resisting the presence of Indian in the contested geographical space in Zimbabwe.

\section{Conclusion}

The Indian diaspora community has been targeted in their host country/countries because of their economic prosperity. The Indian diaspora community in Zimbabwe was targeted because of their economic positioning. The authoritative regime under the leadership of Robert Mugabe led to political crisis in Zimbabwe and the reason for the increasing insecurity of the Indians. Largely the dissatisfaction and the hostility on the part of native communities towards the Indians brought the insider and outsider debate on the surface. This incident brought in the issues of identity and resource conflict between these two communities in Zimbabwe. The minority Indians who have gone through all hardships in Zimbabwe and could able to establish themselves, do not have an easy life. They are frequently pushed to a situation of vulnerability as far as their social insecurity is concerned. The Zimbabweans consider the Indians as a threat and obstacle to their development (Lorenz and Weinberger, 1999, p. 314).

In this context, there is a significant role for the state. The state should initiate the measures to maintain the balanced and cordial relationship between the native communities and the Indian diaspora in Zimbabwe. The Indian diaspora community should also understand the reasons that generated the feeling of marginalisation among the native Zimbabwean communities and respect their genuine rights in terms of their access to natural resources and state sponsored benefits, opportunities and entitlements. On the contrary, the native communities of Zimbabwe should also understand the situation of Indian diaspora and recognise the later's contribution towards the economic development of the country. The failure to maintain balance between these 
two standpoints would continue to reinforce the ethnic differences and thereby would lead to contested and conflicting relationship between the native communities and the Indian diaspora in Zimbabwe.

\section{References}

1. Ambagudia, J. (2019). Adivasis, migrants and the state in India. London and New York: Routledge.

2. Brass, P. R. (1985). Ethnic groups and the state. In Paul R. Brass (ed.), Ethnic groups and the state (pp. 1-56). London and Sydney: Croom Helm

3. Brinkerhoff, J. M. (2011). Diasporas and conflict societies: Conflict entrepreneurs, competing interests or contributors to stability and development?. Conflict, Security and Development, 11(2), 115-143.

4. Butcher, T. (2002, April 25). Mugabe prepares to turn on Asian traders. The Telegraph, Retrieved from https://www.telegraph.co.uk/news/worldnews/africaandindianocean/ zimbabwe/1392210/Mugabe-prepares-to-turn-on-Asian-traders.html.

5. Collier, P. (2000). Economic causes of civil conflict and their implications for policy. Washington D.C.: World Bank.

6. Dotson, F., \& Dotson, L. O. (1968). The Indian minority of Zambia, Rhodesia and Malawi. New Haven and London: Yale University Press.

7. Feron, E., \& Left, B. (2019). Diasporas and conflict: Understanding the Nexus. Diaspora Studies, 12(1), 34-51.

8. Government of India. (n.d.). Population of the overseas Indians. New Delhi: Ministry of External Affairs. Retrieved from http://mea.gov.in/images/attach/NRIs-and-PIOs_ 1.pdf.

9. Gurr, T. R. (1970). Why men rebel. Princeton: Princeton University Press.

10. Horowitz, D. (1985). Ethnic groups in conflict. Berkeley: University of California Press.

11. FAO. (n.d.). Zimbabwe. Retrieved from http://www.fao.org/3/y4632e/y4632e0y.htm.

12. Lorenz, D. C. G., \& Weinberger, G. (1999). Insiders and outsiders: Jewish and gentile culture in Germany and Australia. Detroit: Wayne State University Press.

13. Mariani, F., Mercier, M., \& Verdier, T. (2018). Diasporas and Conflict. Journal of Economic Geography, 18, 761-793.

14. Mlambo, A. S. (1998). Building a white man's country: Aspects of white immigration into Rhodesia up to World War II. Zambezia, 25(2), 123-146.

15. Moyo, S. (2000). The political economy of land acquisition and redistribution in Zimbabwe, 1990-1999. Journal of Southern African Studies, 26(1), 5-28.

16. Muzondidya, J. (2004). Zimbabwe for Zimbabweans: Invisible subject minorities and the quest for justice and reconciliation in postcolonial Zimbabwe. In B. Raftopoulos and T. Savage (Eds.), Zimbabwe: Injustice and political reconciliation (pp. 213-235). Cape Town, South Africa: Institute for Justice and Reconciliation.

17. Muzondidya, J. (2010). The Zimbabwean crisis and the unresolved conundrum of race in the post-colonial period. Journal of Developing Societies, 16(1), 5-38. 
18. PTI. (2017, November 15). Indians in Zimbabwe safe after unrest: Embassy, The New Indian Express. Retrieved from https://www.newindianexpress.com/pti-news/2017/ nov/15/indians-in-zimbabwe-safe-after-unrest-embassy-1702084.html.

19. Shain, Y. (2002). The role of diasporas in conflict perpetuation or resolution, SAIS Review, 12(2), 115-144.

20. The Herald. (2012, November 29). Affirmative action is about change. The Herald. Retrieved from https://www.herald.co.zw/affirmative-action-is-about-change/.

21. Van Hear, N., \& Cohen, R. (2016). Diaspora and conflict: Distance, contiguity and spheres of engagement, Oxford Development Studies, 45, 171-184.

22. Yinger, J. M. (1997). Ethnicity: Source of strength? source of conflict?. Jaipur: Rawat Publications.

23. Zee News. (2002, April 25). Mugabe supporters to turn heat on Indian settlers. Retrieved from https://zeenews.india.com/news/nation/mugabe-supporters-to-turnheat-on-indian-settlers_39937.html. 